\title{
Uterine inflammation and fertility of beef cows subjected to timed AI at different days postpartum
}

\author{
Luiz Francisco Machado Pfeifer ${ }^{\mathrm{a}, *}$, Jéssica de Souza Andrade ${ }^{\mathrm{b}}$, \\ Elizângela Mírian Moreira ${ }^{a}$, Renata Reis da Silva ${ }^{a}$, Paulo Marcos Araújo Neves ${ }^{c}$, \\ George Moreira da Silva ${ }^{\mathrm{d}}$, Izabela Cristina Lemos ${ }^{\mathrm{d}}$, Augusto Schneider ${ }^{\mathrm{e}}$

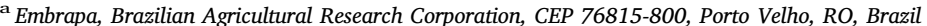 \\ ${ }^{\mathrm{b}}$ Bionorte, Programa de Pós-Graduação em Biodiversidade e Biotecnologia, CEP 76815-800, Porto Velho, RO, Brazil \\ ${ }^{\mathrm{c}}$ UNIR, Universidade Federal de Rondônia, Programa de Pós-Graduação em Ciências Ambientais, CEP 76940-000, Rolim de Moura, RO, Brazil \\ d UNIR, Universidade Federal de Rondônia, Programa de Pós-Graduação em Desenvolvimento Regional e Meio Ambiente, CEP 76815-800, Porto \\ Velho, RO, Brazil \\ e UFPel, Universidade Federal de Pelotas, CEP 96010-610, Pelotas, RS, Brazil
}

\section{A R T I C L E I N F O}

\section{Keywords:}

Calving

Cytobrush

Cytokines

PMN cell

\begin{abstract}
A B S T R A C T
The aim of this study was to evaluate the uterine health and fertility of postpartum beef cows subjected to timed AI (TAI) protocols at different days from calving. Lactating Nelore cows (Bos indicus; $n=244$ ) were used in this study. The TAI protocols were initiated between 20 and 60 days postpartum (DPP). Cows were subjected to an estradiol-progesterone based TAI protocol. The cows were divided into three groups according to the days postpartum at the time the hormonal treatment was initiated: 1) Early $(n=64)$, cows between 20 and 30 DPP; 2) Middle ( $n=115$ ), cows between 31 and 45 DPP; and 3) Late $(n=65)$, cows between 46 and 60 DPP. At Day 0 of the protocol, endometrial cytobrush samples were collected. Slides for polymorphonuclear (PMN) cell counting were prepared and cytobrush was used for RNA extraction and analysis of relative abundance of $i l 1, i l 6, i l 8$, and $\operatorname{tnf}$ mRNA. Cows from the Early group had less $(P<0.05)$ pregnancies per AI (P/AI) than cows from Middle and Late groups; $29.7 \%(19 / 64)$, $45.2 \%(52 / 115)$, and $52.31 \%(34 / 65)$, respectively. Accordingly, the Early group had a greater $(P<0.05)$ proportion of PMN cells in the uterus than Middle and Late groups; $9.0 \%, 3.8 \%$, and $2.2 \%$, respectively. Relative abundances of $i l 1$ and il8 mRNA were greater $(\mathrm{P}<0.05)$ in the Early group than Middle and Late groups. These results indicate that beef cows subjected to TAI protocols early postpartum ( $<30 \mathrm{DPP}$ ) are less likely to become pregnant, which is associated with increased inflammation and relative abundance of mRNA for the proinflammatory cytokines il1 and ils.
\end{abstract}

\section{Introduction}

The use of artificial insemination (AI) protocols for which there is a combining of progesterone and estrogens to improve AI submission rates provides consistent conception results $(\sim 50 \%)$ in postpartum beef cows (Sales et al., 2012). This reproductive technology has made it possible to AI suckled beef cows without the need to detect estrus (Baruselli et al., 2004). The most common

\footnotetext{
* Corresponding author at: Embrapa Rondônia, BR 364 - Km 5,5 - Zona Rural, Caixa postal: 127, CEP: 76815-800, Porto Velho, RO, Brazil.

E-mail address: luiz.pfeifer@embrapa.br (L.F. Machado Pfeifer).
} 
timed AI (TAI) protocol for beef cows maintained in tropical areas consists of an intravaginal progesterone insert, estradiol benzoate (EB) to induce synchronous ovarian follicular wave emergence, prostaglandin F2a analogues (PGFs) to induce luteolysis, and an ovulatory stimulus using an ester of estradiol (benzoate or cypionate).

Several studies have been performed to evaluate the factors that affect the fertility of postpartum cows submitted to TAI protocols, such as: hormone concentration, duration of progestagen treatments, time and dose of PGF2 alpha (PGF) injection, ovulation induction agent, estrous cyclicity status, parity, ovarian response, use and dose of eCG, proportion of cows displaying estrus before AI, body condition score (BCS) of the cows, among others (Meneghetti et al., 2009; Sa Filho et al., 2009, 2011; Ayres et al., 2014; Pfeifer et al., 2017). In none of these previous studies was there an evaluation of the effect of uterine health on the fertility of postpartum beef cows subjected to TAI.

The complete postpartum uterine involution is necessary to promote the successful establishment of a pregnancy. The effects of age and milk yield (Fonseca et al., 1983), dystocia (Sheldon and Dobson, 2004), hypocalcemia, metritis and endometritis (Fonseca et al., 1983; Sheldon, 2004; Roche, 2006), among others, can negatively affect uterine involution and the capacity to support pregnancy. After 3 weeks postpartum, the sloughing of necrotic tissue and hemorrhaging have ceased. Both, the weight of the uterus and the diameter of the previously pregnant horn have decreased more than $80 \%$ during this period. Grossly, both the weight and the size of the uterus have become static by 40 days postpartum and the uterine epithelium has been completely repaired (Call, 1989).

Endometritis is either uncommon in beef cows, or has a limited impact on subsequent reproductive performance (Santos et al., 2009). Dairy cows with persistent subclinical endometritis, however, were at substantially increased risk of failure to become pregnant before the end of the breeding season (Gilbert et al., 2005). Subclinical endometritis (SEM) is an inflammatory condition of the uterus in the absence of clinical signs, and is characterized by the infiltration of polymorphonuclear cells (PMN, mainly neutrophils) in the endometrium, resulting in a significant reduction of the reproductive performance (Kasimanickam et al., 2004; Sheldon et al., 2009; Ricci et al., 2017). The SEM can be as great as 26\% in occurrence between 40 and 60 days postpartum (DPP) in dairy cows (Cheong et al., 2011), and 23\% of occurrence after 50 DPP in beef cows (Ricci et al., 2015). Furthermore, associated with the infiltration of PMN cells in the uterus of dairy cows during puerperium, numerous proinflammatory cytokines and chemokines, including Interleukin (IL)- $1 \beta$, IL- 6 , and IL- 8 and tumor necrosis factor- $\alpha$ (TNF- $\alpha$ ) are produced. Although the changes in gene expression of these cytokines are well characterized in dairy cows (Galvao et al., 2011; Ghasemi et al., 2012), there are few reports for beef cows (Foley et al., 2012). The effect of uterine inflammatory secretion in postpartum beef cows raised extensively and under tropical conditions, therefore, is unknown and information in this regard is lacking.

In healthy cows, uterus reparation is not complete until the sixth week postpartum (Call, 1989; Dadarwal et al., 2017; Sheldon, 2004). Considering the need for intensive breeding in tropical cattle production systems, TAI protocols are conventionally initiated as early as 30 to 60 days postpartum (Sa Filho et al., 2009; Vasconcelos et al., 2009; Sa Filho et al., 2010, 2011; Sales et al., 2011, 2012; Pfeifer et al., 2014). Results of all these studies indicated that there were acceptable P/AI ranging from $46 \%$ to $65 \%$. In few studies, however, has there been a comparison of the effect of days postpartum on P/AI and in none of the previous studies was there an evaluation of the relationship between uterine health and fertility to determine the optimal postpartum period to the onset of a TAI protocol in beef cows. Setting a minimum DPP, therefore, to include postpartum beef cows in TAI programs can improve reproductive efficiency.

Based on these considerations, the objective of the present study was to evaluate the uterine health and fertility of beef cows subjected to TAI protocols at different days in the postpartum period. The hypotheses was tested that beef cows subjected to TAI early after parturition would have a greater number of inflammatory cells and cytokines in the uterus and be less likely to become pregnant.

\section{Materials and methods}

The Committee for Ethics in Animal Experimentation from Embrapa approved all of the procedures performed in the experiment described in this manuscript (Protocol 03/2017).

\subsection{Animals, hormonal treatments and sampling}

Multiparous lactating Nelore cows (Bos indicus; $n=244$ ), 4 to 10 years old, from two comercial beef farms in Rondônia - Brazil, were used in this study. All cows were maintained on Brachiaria brizantha pasture and given mineralized-salt and free access to water. The TAI protocols were initiated between 20 and 60 days postpartum (DPP). Cows were given 2 mg of estradiol benzoate (Bioestrogen ", Biogénesis-Bagó, Curitiba, Brazil) intramuscular (i.m.) and received an intravaginal progesterone-releasing device (1.9 g progesterone, CIDR ${ }^{\oplus}$, Pfizer Animal Health, São Paulo, Brazil) to synchronize follicular wave emergence on Day 0. The CIDR was removed and cows were given $150 \mu$ D D-Cloprostenol i.m. (PGF2 $\alpha$-analogue; Croniben , Biogénesis-Bagó, Curitiba, Brazil), 1 mg of ECP im (E.C.P. ${ }^{\circledR}$, Pfizer, Cravinhos, Brazil), and 300 IU of eCG (Novormon ${ }^{\circledR}$, Syntex, Buenos Aires, Argentina) i.m. on Day 8. All cows were TAI $48 \mathrm{~h}$ after CIDR removal.

Semen from two Nellore bulls at each farm was used for TAI and was equally distributed among treatments. The AI procedures were performed by one experienced technician at each farm. Serum $\beta$-hydroxybutyrate (BHB) concentrations were measured on Day 0 with a hand meter device (TD $-4235^{\circ}$; Ketovet, MG, Brazil). 


\subsection{Experimental design and uterine health evaluation}

The cows were divided into three groups according to the days postpartum (PP) when the hormonal treatment was initiated, as follows: 1$)$ Early PP $(n=64)$, cows between 20 to 30 DPP; 2$)$ Middle PP $(n=115)$, cows between 31 to 45 DPP; and 3$)$ Late PP $(n=65)$, cows between 46 to $60 \mathrm{DPP}$, on the Day 0 of the TAI protocol.

A subset of cows $(n=148)$ was examined by vaginoscopy to evaluate and characterize the presence of vaginal discharge (Pleticha et al., 2009) on Day 0 of the TAI protocol. For vaginoscopic examination, the vulva was cleaned with a paper towel, and a sanitized vaginal speculum was introduced into the vaginal canal. Using a light source, the cervix and the vaginal canal were inspected, and the presence of secretion was classified and registered. Vaginal discharge was graded on a scale from 0 to 3 ( $0=$ mucus, $1=$ mucus with flecks of pus, $2=\geq 50 \%$ purulent exudate, 3 = hemorrhagic and/or purulent exudate), as adapted from others (Williams et al., 2005; Sheldon et al., 2006). Cows with positive purulent vaginal discharge (PVD +) were defined as cows having a vaginal discharge score of one or more.

The same subset of cows from vaginoscopy was selected to collect samples from endometrium. For these purposes, an adapted cytological brush was coupled to the tip of a conventional AI equipment, covered by a disposable AI sheath and protected by a sanitary sheath, as described elsewhere (Cardoso et al., 2017). The apparatus was inserted via cervix and the cytobrush was rotated to collect cells from uterine body. Immediately after the sampling, the cytobrush was uncoupled from the apparatus and was gently rolled onto a clean microscope slide using only half of its entire circumference, to ensure that a suitable quantity of cellular material remained on the untouched surface for gene expression analysis. Slides were air-dried and packaged for transport to the research laboratory. The cytobrush was then placed in a 2 -mL cryotube filled with $1 \mathrm{~mL}$ of RNA later buffer and stored at $-80^{\circ} \mathrm{C}$ for later processing. In the laboratory, the slides were stained using a commercial kit (Quick Panoptic ${ }^{\circ}$, Laborclin, Pinhais, Brazil). Two hundred cells per slide were counted in an optical microscope (100 times magnification), including PMN, mononuclear and epithelial cells to calculate the proportion of PMN cells.

\subsection{Ultrasonic examinations}

On the morning of Day 10 (07:00 a.m.), the diameter of the preovulatory follicle (POF) was assessed in a subset of cows ( $n=138$ ) by ultrasonography (SIUI CTS-900, linear probe with $5 \mathrm{MHZ}$, Guangdong, China). An additional ultrasonic examination was performed $30 \mathrm{~d}$ post-TAI to assess pregnancy status. Visualization of the embryonic vesicle and detection of the embryo were the positive criteria for determining pregnancy.

\subsection{RNA isolation}

Total RNA was extracted from 40 cytobrush samples (14, 11 and 15 samples from Early, Middle and Late groups, respectively). Cells in tubes were pelleted with centrifugation at $2000 \mathrm{x} g$ at $4{ }^{\circ} \mathrm{C}$ for $10 \mathrm{~min}$. Supernatant $(600 \mu \mathrm{L})$ was discarded and $600 \mu \mathrm{L}$ of $1 \%$ $\beta$-mercaptoethanol was added before total RNA was extracted according the commercial kit protocol (PureLink ${ }^{\circledR}$ RNA Mini Kit, Thermo Fisher Scientific, Carlsbad, CA).

Purity and quantity of RNA was assessed using a NanoDrop 2000 spectrophotometer (Thermo Fisher Scientific, USA). The RNA was treated with DNase I (Invitrogen, Thermo Fisher Scientific, USA) before reverse transcription to remove possible genomic DNA contamination.

\section{5. cDNA synthesis and quantitative real-time polymerase chain reaction}

Quantitative real-time polymerase chain reaction (qRT-PCR) was used to assess relative abundance of cytokine mRNAs in the cytobrush samples and was performed by an operator blinded to the cytology results.

First, for cDNA synthesis, the Anchored Oligo primer (dT) 23 (Sigma-Aldrich, USA) was incubated with the treated total RNA at $70{ }^{\circ} \mathrm{C}$ for $10 \mathrm{~min}$, as described by the manufacturer. Then the reverse transcription (RT) reaction was performed using the HighCapacity cDNA kit (Applied Biosystems, USA) according to the protocol described by the manufacturer, in a final volume of $20 \mu \mathrm{L} /$ reaction, using the following conditions: $25^{\circ} \mathrm{C}$ for $10 \mathrm{~min}, 37^{\circ} \mathrm{C}$ for $120 \mathrm{~min}$ and $85^{\circ} \mathrm{C}$ for $5 \mathrm{~min}$. The synthesized cDNA was subsequently quantified by spectrophotometry (NanoDrop 2000 spectrophotometer; Thermo Fisher Scientific, USA) to assess the RT reaction efficiency, and was stored at $-80^{\circ} \mathrm{C}$ until quantitation assessments were conducted.

The Perfecta SsoFast EvaGreen Supermix ${ }^{\mathrm{TM}}$ Kit (Bio-Rad Laboratories Inc., USA) was used according to the manufacturer's instructions to perform qRT-PCR analysis of relative abundance of il1 $\beta$, il6, ils, thfo, GAPDH, and Bactin mRNA. Briefly, $10 \mu \mathrm{L}$ of Perfecta SsoFast EvaGreen ${ }^{\circ}$ master mix for iQ (2X), $1 \mu \mathrm{L}$ of the appropriate primer set (Table 1) at $10 \mu \mathrm{M}$, ultrapure water in a volume of $4 \mu \mathrm{L}$, and $4 \mu \mathrm{L}$ of cDNA template was added for a final reaction volume of $20 \mu \mathrm{L}$.

The reaction was performed in the Bio-Rad CFX96 ${ }^{\mathrm{TM}}$ detection system (Bio-Rad Laboratories Inc., Singapore) using the following program: 1 cycle at $95^{\circ} \mathrm{C}$ for $5 \mathrm{~s}, 39$ cycles of $95^{\circ} \mathrm{C}$ for $5 \mathrm{~s}, 60^{\circ} \mathrm{C}$ for $20 \mathrm{~s}$, and a melting curve standardized from a variable annealing temperature ramp from 65 to $95^{\circ} \mathrm{C}$ with an increase of $0.5^{\circ} \mathrm{C}$ every $5 \mathrm{~s}$. Samples were amplified in duplicate and a melt curve was completed after each PCR reaction to ensure fluorescence quantification was specific to a single PCR product. Both no-template and no-reverse transcriptase controls were utilized to verify DNA-free status of the negative control samples.

The changes in gene expression were calculated by the $2^{\Delta \Delta \mathrm{Ct}}$ method (Livak and Schmittgen, 2001) using the selected references genes ( $\beta$ actin and GAPDH). The first control sample was expressed as 1.00 by this equation, and all other samples were calculated in 
Table 1

Primer sequences for quantitative real-time polymerase chain reaction (qRT-PCR) amplification of mRNA.

\begin{tabular}{lll}
\hline Gene & Primer direction & Primer sequence (5'- 3') \\
\hline \multirow{2}{*}{ GAPDH } & forward & ACACTGAGGACCAGGTTG \\
\multirow{2}{*}{ kactin } & reverse & TGGTCGTTGAGGGCAATG \\
\multirow{2}{*}{$\beta$} & forward & AGGCATCCTGACCCTCAAGTA \\
& reverse & GCTCGTTGTAGAAGGTGTGGT \\
$i l 6$ & forward & CAAGGAGAGGAAAGAGACA \\
& reverse & TGAGAAGTGCTGATGTACCA \\
$i l 8$ & forward & CCAGGAACGAAAGAGAGC \\
tnfa & reverse & CAGAAGTCATCACCAGGAG \\
& forward & CAAGAGCCAGAAGAAACCTGAC \\
& reverse & AGTGTGGCCCACTCTCAATAAC \\
& forward & CTCTTCTGCCTGCTGCACTTC \\
& reverse & CCATGAGGGCATTGGCATACG \\
\hline
\end{tabular}

relation to this value. Afterward, the results in the control group Early PP) were averaged, and all other outputs were divided by the mean value of the relative abundance in the control group to yield the fold change of the genes of interest compared to the control group (Masternak et al., 2005).

\subsection{Statistical analyses}

Statistical analysis was performed using SAS using the Student's $t$-test diameter of the largest follicle, proportion of PMN cells, and concentration of BHA. The Mann-Whitney test was used for analysis of relative abundances of mRNA. Pregnancy per AI and proportion of cows PVD + were analyzed using the chi-square test. To calculate the probability of pregnancy according to the proportion of PMN cells in the uterus, cows were categorized in five classes, and then odds ratios (OR) and 95\% confidence intervals (CI) were generated. Results were presented as proportions and OR. Optimal cut-off points for determining the relationship between the DPP and pregnancy status and between proportion of PMN in the uterus and pregnancy were calculated using receiver operating characteristic (ROC) curve. Specificity (Sp), sensitivity (Se), area under the curve (AUC) and $P$-value of the ROC test are reported. The relationship between the proportion of PMN cells in the uterine endometrium and DPP was determined by linear regression. $P$-values that were less than 0.05 were considered to be significant.

\section{Results}

\subsection{Fertility and metabolic responses}

Data for fertility responses are summarized in Table 2. Cows from the Early group had a lesser $(P<0.05)$ pregnancy per AI $(\mathrm{P} /$ AI) than cows from Middle and Late groups (Table 2). There was no difference $(P>0.05)$ in the diameter of the POF dominant follicle at TAI among groups (Table 2).

Blood concentrations of BHB, according to postpartum group, are depicted in Fig. 1. Cows from Middle group had lesser concentrations of BHB than cows from Late Group $(P<0.01)$. Concentration of BHB in cows from the Early group, however, was not different in comparison to the other groups.

Table 2

Fertility response of cows according to the period at postpartum TAI protocol.

\begin{tabular}{|c|c|c|c|c|}
\hline \multirow[t]{2}{*}{ Parameters } & \multicolumn{3}{|l|}{ Group } & \multirow[b]{2}{*}{ P-Value } \\
\hline & Early & Middle & Late & \\
\hline Proportion of $\mathrm{PMN}^{*}$ cells ${ }^{1}(\%)$ & $9.03 \pm 1.47^{\mathrm{A}}$ & $3.83 \pm 0.72^{\mathrm{B}}$ & $2.23 \pm 0.42^{\mathrm{B}}$ & $<0.001$ \\
\hline Cows with PVD $+1, \ldots * *$ & $45 \%{ }^{\mathrm{A}}(23 / 51)$ & $18 \%{ }^{\mathrm{B}}(9 / 50)$ & $15 \%{ }^{\mathrm{B}}(7 / 47)$ & $<0.001$ \\
\hline Diameter of the ovulatory follicle $(\mathrm{mm})^{2}$ & $12.1 \pm 0.4$ & $12.2 \pm 0.3$ & $12.5 \pm 0.5$ & 0.8 \\
\hline Pregnancy per $\mathrm{AI}^{3}$ & $29.7 \%^{\mathrm{A}}(19 / 64)$ & $45.2 \%^{\mathrm{B}}(52 / 115)$ & $52.3 \%^{\mathrm{B}}(34 / 65)$ & 0.02 \\
\hline
\end{tabular}

\footnotetext{
${ }^{\mathrm{AB}}$ Within a row, means without a common superscript differed $(P<0.05)$.

* Polymorphonuclear cells.

** Based on the vaginal discharge.

1 Vaginal discharge and proportion of PMN cells were observed in a subgroup of cows (148 of 244 ) on Day 0.

2 Diameter of the ovulatory follicle were observed in a subgroup of cows (138 of 244) on Day 10.

3 All cows.
} 


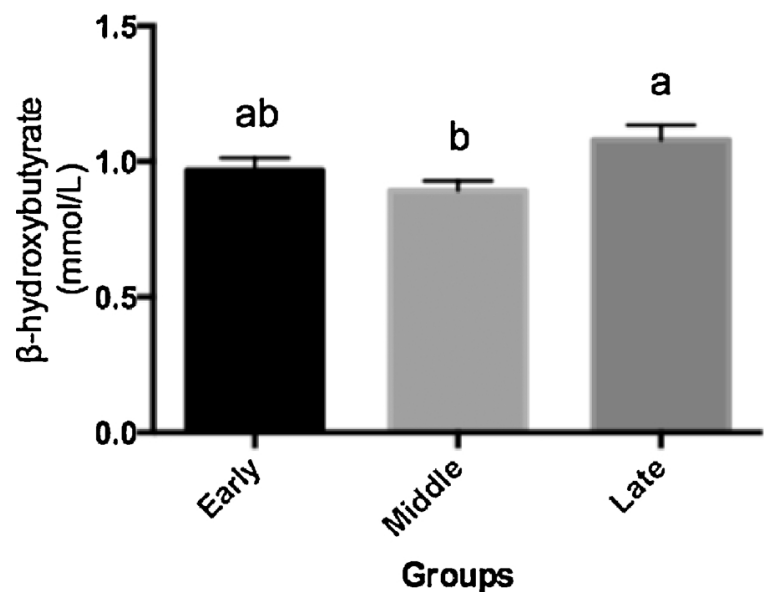

Fig. 1. Plasma concentration of $\beta$-hydroxybutyrate (BHB) for postpartum beef cows submitted to timed AI at different times in the postpartum period; Different letters indicate differences among groups $(P<0.05)$.

\subsection{Uterine health and relative abundance of pro-inflammatory cytokine $m R N A$}

The proportion of PMN cells in the uterus and the proportion of cows with PVD + are shown in Table 2. Cows from the Early group had a greater $(P<0.001)$ proportion of PMN cells in the uterus than the Middle and Late groups. Similarly, the proportion of cows with PVD + was greater in the Early group than Middle and Late groups $(P<0.001)$. Independent of days postpartum, cows with a lesser proportion $(<2.5 \%)$ of PMN cells in the uterus were 11.8 times more likely to become pregnant than cows with a greater proportion $(>15 \%)$ of PMN cells $(P<0.001$; Table 3$)$.

The linear regression model indicates a negative relationship between DPP and proportion of PMN in the uterine endometrium (Fig. 2; \% PMN = 13.3-0.23*DPP; $r=0.36 ; P<0.001$ ). Based on the ROC curve, a cut-off point of $>35.5$ DPP was correlated with pregnancy status at TAI; this optimal cut-off point presented $69.5 \%$ of specificity and $48.2 \%$ of sensitivity (AUC $=0.58, P=0.01$; Fig. 3). Furthermore, a cut-off point of 5\% of PMN (Sp 57\%, Se 79\%; Fig. 4A), of 2.5\% of PMN (Sp 68\%, Se 70\%; Fig. 4B), and of 1\% of PMN (Sp 75\%, Se 50\%; Fig. 4C), were correlated with pregnancy status at TAI for Early, Middle and Late postpartum groups, respectively.

The relative abundance of proinflammatory cytokine $i l 1 \beta$, il6, ils, and tnf $\alpha$ mRNA is depicted in Fig. 5. Data are reported as $\Delta \mathrm{Ct}$ relative to the housekeeping genes, Bactin and GAPDH. There was no difference in the control ( $\beta$ actin and GAPDH) Ct values between groups ( $P=0.22 ; 24.4,23.9$, and 24.8 in cows from Early, Middle and Late groups, respectively). The consistency of abundance of Bactin and GAPDH mRNA confirms the suitability as reference genes. Relative abundance of mRNA transcripts for il6 and tnfa did not change among groups. In contrast, relative abundance of the mRNA transcripts for $i l 1 \beta$ and il8 was greater $(\mathrm{P}<0.05)$ in the Early group than Middle and Late groups.

\section{Discussion}

The aim of the present study was to explore the associations between the proportion of PMN in the uterus, the gene expression of inflammatory cytokines and fertility of TAI protocols in postpartum beef cows. The results of the current study supported the hypotheses for the present study. Cows subjected to TAI protocols early postpartum ( $\leq 30$ days), had a lesser P/AI and greater proportion of PMN, greater uterine discharge, and greater relative abundance of mRNA transcripts for il1 $\beta$ and ils in the uterine endometrium. Importantly, independent of days postpartum cows with a lesser proportion of uterine PMN had a greater P/AI. To the best of our knowledge this is the first report to indicate a cutt-off of 35 DPP as a voluntary waiting period to include beef cows in estradiol-progesterone based TAI protocols. Results from earlier studies, however, have documented that AI performed after an estrus occurring before 20 DPP would not result in pregnancies (Short et al., 1972) and that the interval from calving to first estrus and to

Table 3

Risk factor for occurrence of pregnancy according to the proportion of PMN cells in uterus in timed AI postpartum beef cows.

\begin{tabular}{lll}
\hline Proportion of PMN cells, & P/AI, \% & OR $(95 \% \mathrm{CI})$ \\
\hline $0-2.5 \%$ & $54.2(45 / 83)^{\mathrm{A}}$ & $11.8(1.45-96.80)$ \\
$3-6.5 \%$ & $40.0(10 / 25)^{\mathrm{A}}$ & $6.7(0.73-60.55)$ \\
$7-10.5 \%$ & $36.8(7 / 19)^{\mathrm{A}}$ & $5.8(0.61-55.77)$ \\
$11-15 \%$ & $10.0(1 / 10)^{\mathrm{B}}$ & $1.1(0.06-20.50)$ \\
$>15 \%$ & $9.1(1 / 11)^{\mathrm{B}}$ & Reference \\
\hline
\end{tabular}

${ }^{\mathrm{AB}}$ Within a column, means without a common superscript differed $(P<0.05)$. 


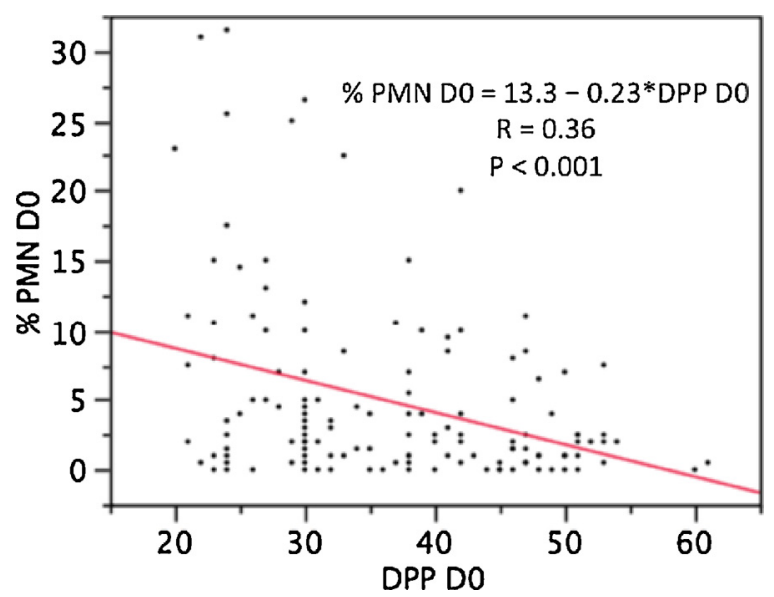

Fig. 2. Relationship between proportion of PMN cells in the uterine endometrium and Days Postpartum in Nelore cows subjected to TAI protocol.

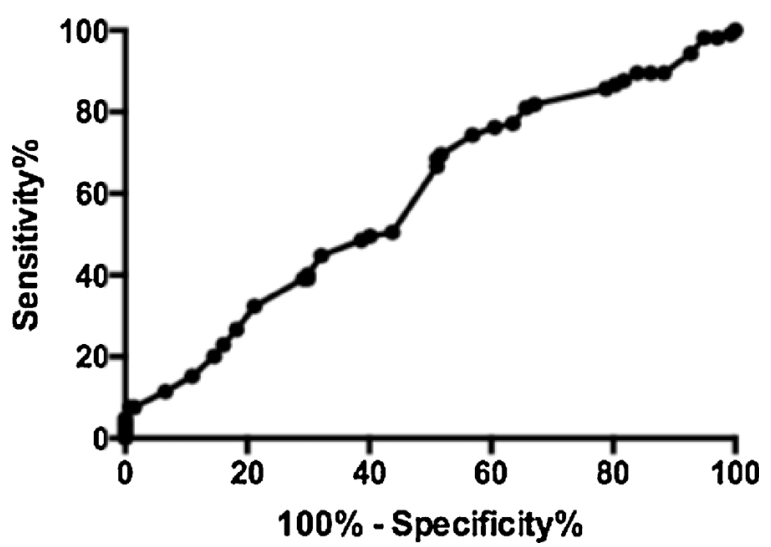

Fig. 3. Receiver Operating Characteristic (ROC) curve for determining the relationship between the DPP and pregnancy status in beef cows; Analysis of the ROC indicated that the use of a cut-off point of more than 35.5 DPP was $69.5 \%$ specific and $48.2 \%$ sensitive; Area under the curve $=0.58$, $P=0.01$.

conception is negatively affected by the intensity of suckling (Wettemann et al., 1978) and amount of dietary energy (Wiltbank et al., 1964; Randel, 1990).

In the present study, the proportion of PMN cells decreased with increasing days postpartum. A similar relationship was observed in Angus postpartum cows, in which the proportion of PMN cells in the uterus decreased after 50 days postpartum (Santos et al., 2009). In that previous study, however, $17 \%$ of the cows still had more than $5.5 \%$ of PMN after this period (e.g., $5.5 \%$ of PMN was the cut-off used to determine subclinical endometritis in that study; Santos et al., 2009). In contrast, data from the present study indicate that only $4.8 \%(1 / 21)$ of the cows had $>5.5 \%$ of PMN cells in the uterus after $50 \mathrm{DPP}$, and cows from the Middle group had an average $3.8 \%$ of PMN. This small proportion of PMN is less than the cut-off previously used to determine subclinical endometritis in beef cows at 30 DPP (6.5\%; Ricci et al., 2017). In that regard, cows that resume ovulation earlier postpartum resolve postpartum uterine inflammation more rapidly than those cows in which postpartum ovulation was delayed (Krause et al., 2014). In addition, dairy cows having ovulations earlier postpartum have a reduced incidence of endometritis and increased pregnancy rate (Galvao et al., 2011). Although the time of the first ovulation postpartum was not accessed in the present study, the proportion of cows in anestrous, at the onset of TAI protocol, was presumably greater in cows in the Early than in the other groups. It is important, therefore, to highlight this direct association between days postpartum, occurrence of first ovulation, uterine health and fertility, and the need to establish the most appropriate time for the beginning of the TAI protocol. Unfortunately, because the experiment was performed on commercial beef operations it was not possible to evaluate the presence of a CL to confirm ovulation after the TAI procedures.

Different from B. taurus beef cows (Santos et al., 2009), in the present study, the presence of PMN cells in the uterus of postpartum B. indicus beef cows decreased sharply after 30 DPP. In that regard, the Receiver Operating Characteristic (ROC) curve for determining the relationship between the DPP and pregnancy status indicated a cut-off point of 35.5 DPP. Although the specificity and sensitivity were not great, this result was associated with pregnancy at the first postpartum TAI protocol. The P/AI in cows subjected to TAI $\leq 35$ DPP was $32.6 \%$, while P/AI for cows timed AI after 35 DPP was $50.0 \%$. Furthermore, the proportion of PMN cells in the uterine endometrium in cows sampled with > 35 DPP was $2.9 \%$, in which only $16.6 \%$ of these cows had $>5.5 \%$ PMN. By setting 35 


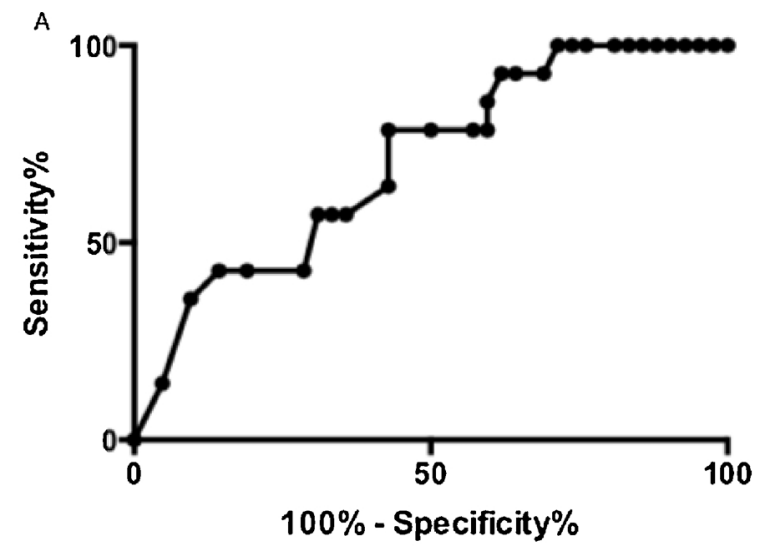

B
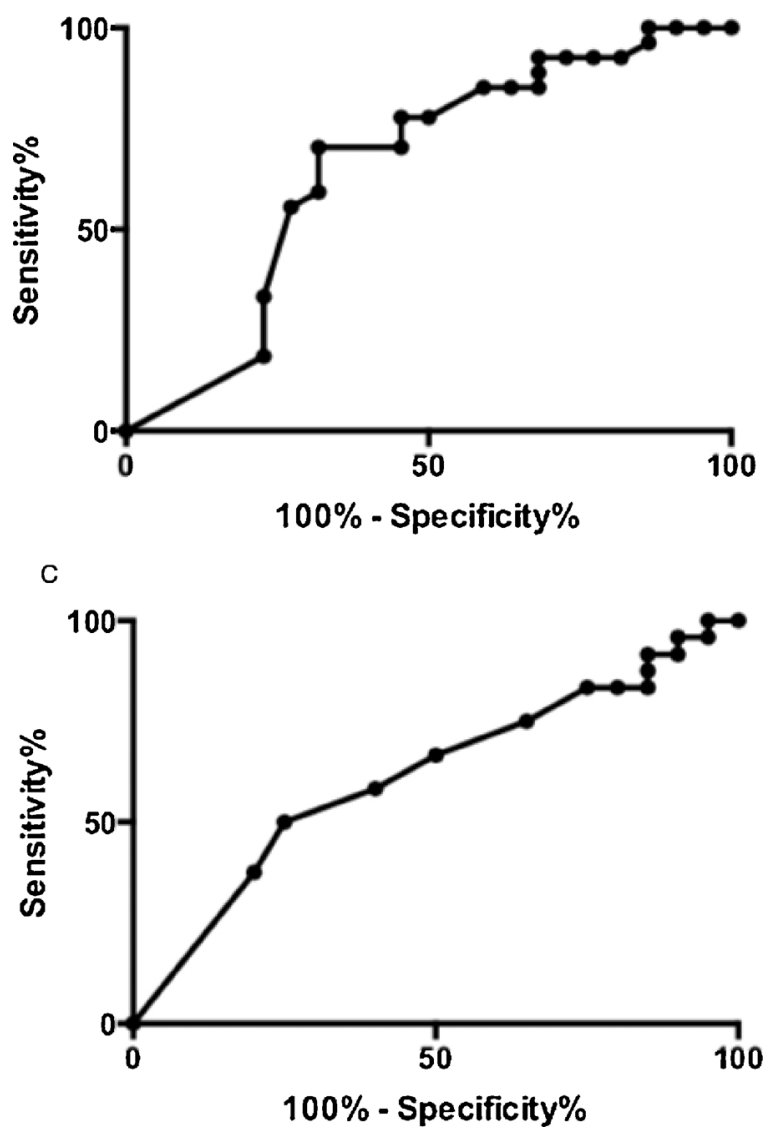

Fig. 4. Receiver Operating Characteristic (ROC) curve for determining the relationship between the proportion of PMN in the uterus and pregnancy status in Early (A), Middle (B), and Late Group (C) postpartum beef cows.

DPP, therefore, as the minimum DPP to include postpartum beef cows for TAI programs there can be an improvement in reproductive efficiency. The results from the present study indicate that cows with adequate DPP and a healthier uterus are more likely to become pregnant at the first TAI postpartum.

The process of uterine involution is not clearly understood, and the measurement of the uterus physical dimensions may not fully represent the underlying cellular and biochemical changes taking place during the postpartum period. The normal range for completion of the uterine involution is 30 to 40 days postpartum (Call, 1989; Sheldon, 2004), thus, if the goal is the production of one calf per year in tropical commercial beef farms, some cows have to be subjected to TAI protocols as early as 30 days parturition. In the present study there are indications that the presence of PMN cells in the endometrium decreases to 60 DPP. Thus, cows from the Early group may not have completed all biochemical and cellular changes needed for complete uterine regression at beginning of the protocol and this can lead to lesser pregnancy rates. From this perspective, the greater proportion of PMN cells in the uterus of these 


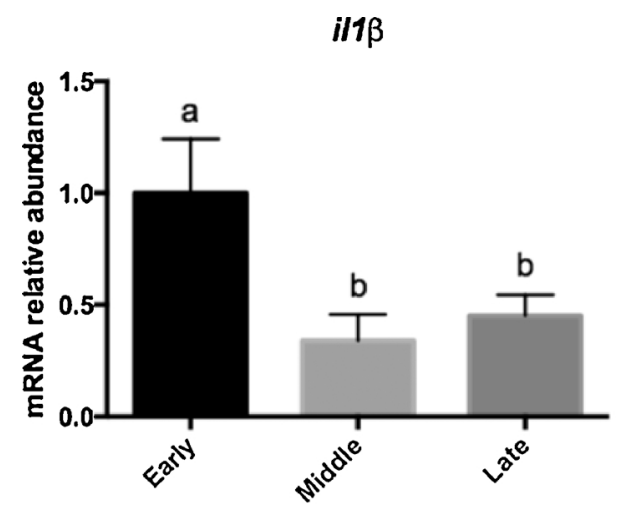

i/6

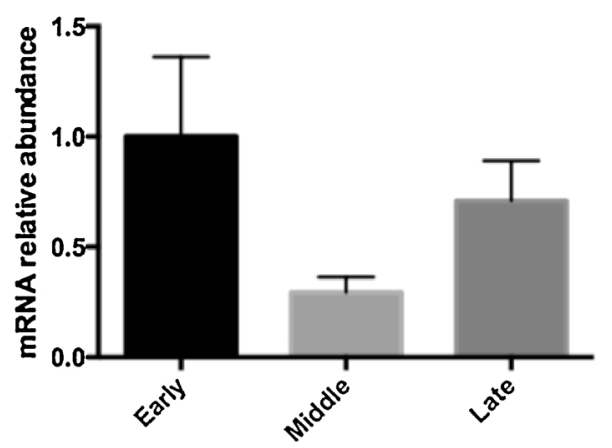

i/8

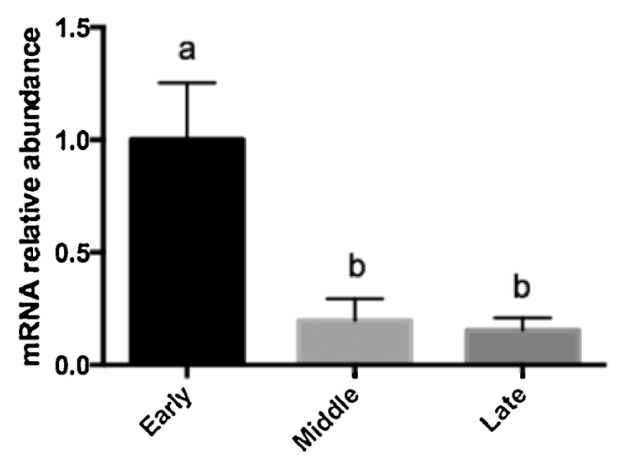

tnfa

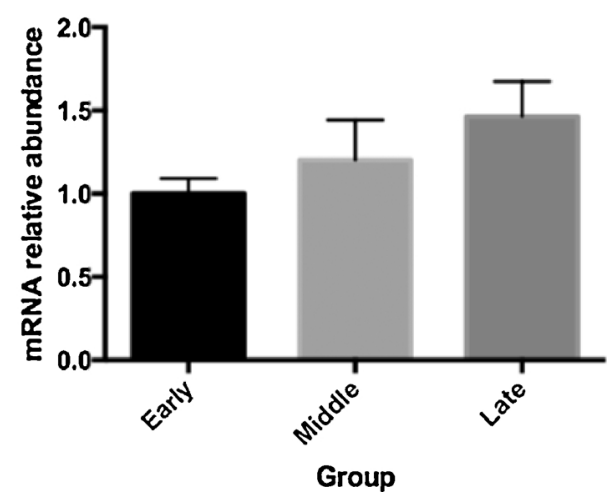

Fig. 5. Relative mRNA transcript abundance in uterine endometrial tissues of beef cows in which timed AI was imposed at different times of the postpartum period; Different letters indicate differences among groups $(P<0.05)$. 
cows provides support for this hypothesis.

During the peripartum period, the stress of pregnancy, parturition, onset of lactation and suckling negatively affect the energy balance (Ciccioli et al., 2003). The transition period in beef cows induces a postpartum negative energy balance (NEB), characterized by elevated concentrations of BHB that indicates a metabolic dysfunction resulting from poor adaptation to NEB (Herdt, 2000). Although, lesser serum BHB concentrations were indicative of improved reproductive performance in beef cows (Mulliniks et al., 2013), in the present study, the greater BHB was observed in the Late group, in which P/AI was also greater. This relatively greater BHB detected in Late group can be associated with the increasing milk production in B. indicus (Oliveira et al., 2007; Jian et al., 2015) and the nadir of BCS after parturition (Diaz et al., 2017; Pfeifer et al., 2017). Bos indicus cows maintained on pastures have a reduction in BCS from parturition until about 80 days postpartum. This use of energy reserves evidenced by metabolic blood changes, however, does not affect the results of conducting a TAI program. Cows from the Late group had a similar diameter of the POF than other groups and had similar P/AI than cows from Middle group. Thus, although the NEB can negatively affect the ovarian follicular development and ovulation (Wiltbank et al., 2002), in the present study, cows from all experimental groups had similar POF diameter.

As previously observed (Ghasemi et al., 2012; Cardoso et al., 2017), the cytobrush technique was useful for collection of endometrial epithelial cells to obtain RNA of sufficient quantity and quality for gene expression analysis. In the present study, large increases in relative abundance of $i l 1 \beta$ and $i l 8$ cytokine mRNAs were associated with a greater proportion of PMN in uterus and lesser P/AI. Inflammatory mediators have a detrimental effect on embryo development (Hill and Gilbert, 2008). Thus, the increased inflammatory mediators present in uterus during puerperium can be detrimental for fertility in cows subjected to TAI early postpartum. During puerperium, numerous proinflammatory cytokines and chemokines, including il1 $\beta$, il6, ils, and tnf $\alpha$ are produced in the uterus (Herath et al., 2006; Ghasemi et al., 2012). Furthermore, resident macrophages also contribute to the inflammatory process by release of cytokines and chemokines after phagocytosis of bacteria (Tzianabos, 2000). Importantly, TNF and IL-1 stimulate expression of chemokine genes (e.g., il-8 and monocyte chemotactic protein-1 (MCP-1)) and adhesion molecules on vascular endothelial cells, leading to neutrophil and monocyte diapedesis and chemoattraction (Sica et al., 1990; Roach et al., 2002). The Il6 gene expression has been associated with the activation of the inflammatory cascade in response to bacterial infection (Galvao et al., 2011; Ghasemi et al., 2012). In the present study, as occurred with the proportion of PMN in the uterus, gene expression of proinflammatory cytokines was greater in samples collected from cows in the Early group.

In conclusion, the proportion of PMN cells decreased rapidly with increasing days postpartum in Bos indicus cows managed in tropical conditions. Consequently, P/AI with use of TAI programs increased with the decreasing of PMN cells in the uterus. As the aim of cattle producers is to produce one calf per year, in South American beef operations, there is imposition of TAI programs on cows as early as 30 DPP. The results from the present study, however, indicate that cows with adequate DPP and a healthier uterus are more likely to become pregnant at first TAI postpartum. Cows subjected to TAI protocols early postpartum ( $\leq 30$ days), have a greater proportion of PMN, greater uterine discharge, and greater abundance of mRNA transcripts for ill $\beta$ and ils in the uterine endometrium. Consequently, this group of cows had a lesser P/AI at TAI. In this regard, the cutt-off of 35 DPP to include cows in TAI programs, observed from ROC analysis, seems reasonable to avoid AI of these cows.

\section{Declaration of interest}

The authors have no conflict of interest to disclose.

\section{Acknowledgments}

This study received fundingsupport from Embrapa (MP1/PC3 Project n. 01.03.14.011.00.00) and from CNPq (Universal Project n: 407307/2016-8). JSA, PMAN, and ICL were supported by CAPES scholarship from the Ministry of Education (ME, Brazil). GMS was supported by CNPq scholarship from the Ministry of Science and Technology (MCT, Brazil) and EMM was supported by FAPERO/ CNPq scholarship. Authors are grateful to Dr. Guilherme Lemos for his help with data collection and herd management during the experimental period. Authors also thank Jose Macedo (Fazenda SK) and Alaor José Carvalho (Fazenda Pau D'alho) for providing animals and facilities to develop this study.

\section{References}

Ayres, H., Ferreira, R.M., Torres-Junior, J.R., Demetrio, C.G., Sa Filho, M.F., Gimenes, L.U., Penteado, L., D’Occhio, M.J., Baruselli, P.S., 2014. Inferences of body energy reserves on conception rate of suckled Zebu beef cows subjected to timed artificial insemination followed by natural mating. Theriogenology $82,529-536$.

Baruselli, P.S., Reis, E.L., Marques, M.O., Nasser, L.F., Bo, G.A., 2004. The use of hormonal treatments to improve reproductive performance of anestrous beef cattle in tropical climates. Anim. Reprod. Sci. 82-83, 479-486.

Call, E.P., 1989. Involution of the uterus of dairy cattle. Kansas Agric. Exp. Stn. Res. Rep. 0, 63-65.

Cardoso, B., Oliveira, M.L., Pugliesi, G., Batista, E., Binelli, M., 2017. Cytobrush: a tool for sequential evaluation of gene expression in bovine endometrium. Reprod. Domest. Anim. 52, 1153-1157.

Cheong, S.H., Nydam, D.V., Galvao, K.N., Crosier, B.M., Gilbert, R.O., 2011. Cow-level and herd-level risk factors for subclinical endometritis in lactating Holstein cows. J. Dairy Sci. 94, 762-770.

Ciccioli, N.H., Wettemann, R.P., Spicer, L.J., Lents, C.A., White, F.J., Keisler, D.H., 2003. Influence of body condition at calving and postpartum nutrition on endocrine function and reproductive performance of primiparous beef cows. J. Anim. Sci. 81, 3107-3120.

Dadarwal, D., Palmer, C., Griebel, P., 2017. Mucosal immunity of the postpartum bovine genital tract. Theriogenology 104, 62-71.

Diaz, R., Galina, C.S., Rubio, I., Corro, M., Pablos, J.L., Rodriguez, A., Orihuela, A., 2017. Resumption of ovarian function, the metabolic profile and body condition in Brahman cows (Bos indicus) is not affected by the combination of calf separation and progestogen treatment. Anim. Reprod. Sci. $185,181-187$. 
Foley, C., Chapwanya, A., Creevey, C.J., Narciandi, J., Morris, D., Kenny, E.M., Cormican, P., Callanan, J.J., O’Farrelly, C., Meade, K.G., 2012. Global endometrial transcriptomic profiling: transient immune activation precedes tissue proliferation and repair in healthy beef cows. BMC Genomics 13 , 489.

Fonseca, F.A., Britt, J.H., McDaniel, B.T., Wilk, J.C., Rakes, A.H., 1983. Reproductive traits of Holsteins and Jerseys: effects of age, milk yield, and clinical abnormalities on involution of cervix and uterus, ovulation, estrous cycles, detection of estrus, conception rate and days open. J. Dairy Sci. 66, 1128-1147.

Galvao, K.N., Santos, N.R., Galvao, J.S., Gilbert, R.O., 2011. Association between endometritis and endometrial cytokine expression in postpartum Holstein cows. Theriogenology 76, 290-299.

Ghasemi, F., Gonzalez-Cano, P., Griebel, P.J., Palmer, C., 2012. Proinflammatory cytokine gene expression in endometrial cytobrush samples harvested from cows with and without subclinical endometritis. Theriogenology 78, 1538-1547.

Gilbert, R.O., Shin, S.T., Guard, C.L., Erb, H.N., Frajblat, M., 2005. Prevalence of endometritis and its effects on reproductive performance of dairy cows Theriogenology 64, 1879-1888.

Herath, S., Fischer, D.P., Werling, D., Williams, E.J., Lilly, S.T., Dobson, H., Bryant, C.E., Sheldon, I.M., 2006. Expression and function of Toll-like receptor 4 in the endometrial cells of the uterus. Endocrinology 147, 562-570.

Herdt, T.H., 2000. Ruminant adaptation to negative energy balance. Influences on the etiology of ketosis and fatty liver. Vet. Clin. North Am. Food Anim. Pract. 16, $215-230$.

Hill, J., Gilbert, R., 2008. Reduced quality of bovine embryos cultured in media conditioned by exposure to an inflamed endometrium. Aust. Vet. J. 86, 312-316.

Jian, W., Ke, Y., Cheng, L., 2015. Physiological responses and lactation to cutaneous evaporative heat loss in Bos indicus, Bos taurus, and their crossbreds. AsianAustralas. J. Anim. Sci. 28, 1558-1564.

Kasimanickam, R., Duffield, T.F., Foster, R.A., Gartley, C.J., Leslie, K.E., Walton, J.S., Johnson, W.H., 2004. Endometrial cytology and ultrasonography for the detection of subclinical endometritis in postpartum dairy cows. Theriogenology 62, 9-23.

Krause, A.R., Pfeifer, L.F., Montagner, P., Weschenfelder, M.M., Schwegler, E., Lima, M.E., Xavier, E.G., Brauner, C.C., Schmitt, E., Del Pino, F.A., Martins, C.F., Correa, M.N., Schneider, A., 2014. Associations between resumption of postpartum ovarian activity, uterine health and concentrations of metabolites and acute phase proteins during the transition period in Holstein cows. Anim. Reprod. Sci. 145, 8-14.

Livak, K.J., Schmittgen, T.D., 2001. Analysis of relative gene expression data using real-time quantitative PCR and the 2 CT method. Methods 25, 402-408.

Masternak, M.M., Al-Regaiey, K.A., Del Rosario Lim, M.M., Bonkowski, M.S., Panici, J.A., Przybylski, G.K., Bartke, A., 2005. Caloric restriction results in decreased expression of peroxisome proliferator-activated receptor superfamily in muscle of normal and long-lived growth hormone receptor/binding protein knockout mice. J. Gerontol. A: Biol. Sci. Med. Sci. 60, 1238-1245.

Meneghetti, M., Sa Filho, O.G., Peres, R.F., Lamb, G.C., Vasconcelos, J.L., 2009. Fixed-time artificial insemination with estradiol and progesterone for Bos indicus cows I: basis for development of protocols. Theriogenology 72, 179-189.

Mulliniks, J.T., Kemp, M.E., Endecott, R.L., Cox, S.H., Roberts, A.J., Waterman, R.C., Geary, T.W., Scholljegerdes, E.J., Petersen, M.K., 2013. Does beta-hydroxybutyrate concentration influence conception date in young postpartum range beef cows? J. Anim. Sci. 91, 2902-2909.

Oliveira, V.C., Fontes, C.A.A., Siqueira, J.G., Fernandes, A.M., Sant'ana, N.F., Neto, A.C.D., 2007. Milk production and performance of calves from Nellore and crossbred cows. Braz. J. Anim. Sci. 36 (Suppl), 2074-2081.

Pfeifer, L.F., Leonardi, C.E., Castro, N.A., Viana, J.H., Siqueira, L.G., Castilho, E.M., Singh, J., Krusser, R.H., Rubin, M.I., 2014. The use of PGF2alpha as ovulatory stimulus for timed artificial insemination in cattle. Theriogenology 81, 689-695.

Pfeifer, L.F.M., Castro, N.A., Neves, P.M.A., Cestaro, J.P., 2017. Development and validation of an objective method for the assessment of body condition scores and selection of beef cows for timed artificial insemination. Livest. Sci. 197, 82-87.

Pleticha, S., Drillich, M., Heuwieser, W., 2009. Evaluation of the Metricheck device and the gloved hand for the diagnosis of clinical endometritis in dairy cows. J. Dairy Sci. 92, 5429-5435.

Randel, R.D., 1990. Nutrition and postpartum rebreeding in cattle. J. Anim. Sci. 68, 853-862.

Ricci, A., Gallo, S., Molinaro, F., Dondo, A., Zoppi, S., Vincenti, L., 2015. Evaluation of subclinical endometritis and consequences on fertlity in Piedmintese beef cows. Reprod. Domest. Anim. 50, 142-148.

Ricci, A., Bonizzi, G., Sarasso, G., Gallo, S., Dondo, A., Zoppi, S., Vincenti, L., 2017. Subclinical endometritis in beef cattle in early and late postpartum: cytology, bacteriology, haptoglobin and test strip efficiency to evaluate the evolution of the disease. Theriogenology $94,86-93$.

Roach, D.R., Bean, A.G., Demangel, C., France, M.P., Briscoe, H., Britton, W.J., 2002. TNF regulates chemokine induction essential for cell recruitment, granuloma formation, and clearance of mycobacterial infection. J. Immunol. 168, 4620-4627.

Roche, J.F., 2006. The effect of nutritional management of the dairy cow in reproductive efficiency. Anim. Reprod. Sci. 96, 282-296.

Sa Filho, O.G., Meneghetti, M., Peres, R.F., Lamb, G.C., Vasconcelos, J.L., 2009. Fixed-time artificial insemination with estradiol and progesterone for Bos indicus cows II: strategies and factors affecting fertility. Theriogenology 72, 210-218.

Sa Filho, M.F., Crespilho, A.M., Santos, J.E., Perry, G.A., Baruselli, P.S., 2010. Ovarian follicle diameter at timed insemination and estrous response influence likelihood of ovulation and pregnancy after estrous synchronization with progesterone or progestin-based protocols in suckled Bos indicus cows. Anim. Reprod. Sci. 120, 23-30.

Sa Filho, M.F., Santos, J.E., Ferreira, R.M., Sales, J.N., Baruselli, P.S., 2011. Importance of estrus on pregnancy per insemination in suckled Bos indicus cows submitted to estradiol/progesterone-based timed insemination protocols. Theriogenology 76, 455-463.

Sales, J.N., Crepaldi, G.A., Girotto, R.W., Souza, A.H., Baruselli, P.S., 2011. Fixed-time AI protocols replacing eCG with a single dose of FSH were less effective in stimulating follicular growth, ovulation, and fertility in suckled-anestrus Nelore beef cows. Anim. Reprod. Sci. 124, 12-18.

Sales, J.N., Carvalho, J.B., Crepaldi, G.A., Cipriano, R.S., Jacomini, J.O., Maio, J.R., Souza, J.C., Nogueira, G.P., Baruselli, P.S., 2012. Effects of two estradiol esters (benzoate and cypionate) on the induction of synchronized ovulations in Bos indicus cows submitted to a timed artificial insemination protocol. Theriogenology 78, 510-516.

Santos, N.R., Lamb, G.C., Brown, D.R., Gilbert, R.O., 2009. Postpartum endometrial cytology in beef cows. Theriogenology 71, 739-745.

Sheldon, I.M., 2004. The postpartum uterus. Vet. Clin. North Am. Food Anim. Pract. 20, 569-591.

Sheldon, I.M., Dobson, H., 2004. Postpartum uterine health in cattle. Anim. Reprod. Sci. 82-83, $295-306$.

Sheldon, I.M., Lewis, G.S., LeBlanc, S., Gilbert, R.O., 2006. Defining postpartum uterine disease in cattle. Theriogenology 65, $1516-1530$.

Sheldon, I.M., Cronin, J., Goetze, L., Donofrio, G., Schuberth, H.J., 2009. Defining postpartum uterine disease and the mechanisms of infection and immunity in the female reproductive tract in cattle. Biol. Reprod. 81, 1025-1032.

Short, R.E., Bellows, R.A., Moody, E.L., Howland, B.E., 1972. Effects of suckling and mastectomy on bovine postpartum reproduction. J. Anim. Sci. 34, 70-74.

Sica, A., Matsushima, K., Van Damme, J., Wang, J.M., Polentarutti, N., Dejana, E., Colotta, F., Mantovani, A., 1990. IL-1 transcriptionally activates the neutrophil chemotactic factor/IL-8 gene in endothelial cells. Immunology 69, 548-553.

Tzianabos, A.O., 2000. Polysaccharide immunomodulators as therapeutic agents: structural aspects and biologic function. Clin. Microbiol. Rev. 13, 523-533.

Vasconcelos, J.L., Sa Filho, O.G., Perez, G.C., Silva, A.T., 2009. Intravaginal progesterone device and/or temporary weaning on reproductive performance of anestrous crossbred Angus x Nelore cows. Anim. Reprod. Sci. 111, 302-311.

Wettemann, R.P., Turman, E.J., Wyatt, R.D., Totusek, R., 1978. Influence of suckling intensity on reproductive performance of range cows. J. Anim. Sci. 47, 342-346.

Williams, E.J., Fischer, D.P., Pfeiffer, D.U., England, G.C., Noakes, D.E., Dobson, H., Sheldon, I.M., 2005. Clinical evaluation of postpartum vaginal mucus reflects uterine bacterial infection and the immune response in cattle. Theriogenology 63, 102-117.

Wiltbank, J.N., Rowden, W.W., Ingalls, J.E., Zimmerman, D.R., 1964. Influence of post-partum energy level on reproductive performance of Hereford cows restricted in energy intake prior to calving. J. Anim. Sci. 23, 1049-1053.

Wiltbank, M.C., Gumen, A., Sartori, R., 2002. Physiological classification of anovulatory conditions in cattle. Theriogenology 57, 21-52. 